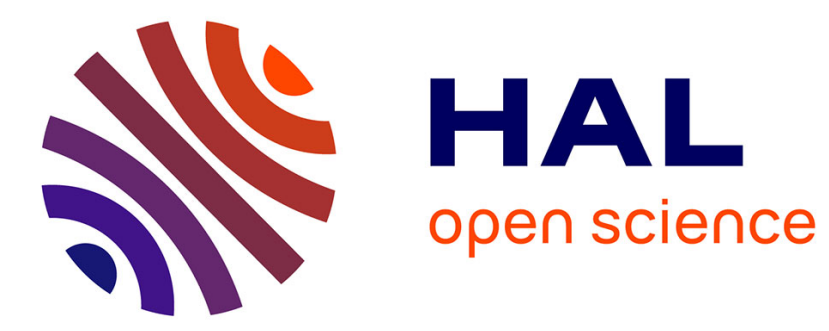

\title{
More Uniform Ferrite Powders through Precise Ceramic Processing
}

M. Ruthner

\section{To cite this version:}

M. Ruthner. More Uniform Ferrite Powders through Precise Ceramic Processing. Journal de Physique IV Proceedings, 1997, 07 (C1), pp.C1-53-C1-56. 10.1051/jp4:1997108 . jpa-00254718

\section{HAL Id: jpa-00254718 https://hal.science/jpa-00254718}

Submitted on 1 Jan 1997

HAL is a multi-disciplinary open access archive for the deposit and dissemination of scientific research documents, whether they are published or not. The documents may come from teaching and research institutions in France or abroad, or from public or private research centers.
L'archive ouverte pluridisciplinaire HAL, est destinée au dépôt et à la diffusion de documents scientifiques de niveau recherche, publiés ou non, émanant des établissements d'enseignement et de recherche français ou étrangers, des laboratoires publics ou privés. 


\title{
More Uniform Ferrite Powders through Precise Ceramic Processing
}

\author{
M.J. Ruthner
}

RTR RUTHNER GmbH, Aichereben 11, 4865 Nussdorf am Attersee, Austria

\begin{abstract}
The ferrite industries are expected to grow continuously and an estimated covering the market development of forthcoming years, in terms of produced annual tonnage, will be presented. The creation of uniform sintered structures, within the lower micron meter range, essentially free of duplex structures, is highly desireable for the production of a large proportion of soft and hard ferrite products. Several wet chemical processes have been proposed and are presently beeing carried out on a commercial scale for the production of ferrite powders. For the production of precisely controlled uncollapsed ferrite powders, exhibiting uniform primary particle sizes within the submicron meter range, should for cost savings, environmental and constant quality control purposes, be carried out at selected and integrated steel mills using short thermal sintering techniques. The advantage of an independent managemant - away from the core business stell - would be of mutual benefit to the ferrite and steel industries.
\end{abstract}

\section{Estimated World Ferrite Production}

An estimate covering the world-wide ferrite production for the period of 1990 up to 2005 is shown in Table 1. The annual growth rates for indicated ferrite applications are expected to vary between 5 and 15 percent. Total marker value of ceramic and plastic bonded ferrites for 1995 may be estimated at 4 billion USS. An estimate indicated in Table 1. is based on provided data of different ferrite grade ferric oxide shipments as well as other sources [1].

Similar forecasts have been presented in the past on occasion of ICF 3 \& ICF 5 conferences [2], [3]. Due to the fact, that the production of ferrites is rather labour intensive, substantial shifting of the production of ferrite cores from industrialized to developing countries has been taking piace. However synthetic ferric oxides exhibiting an attractive price versus performance ratio, which are required for the production of uniform ferrite powders and cores, are to a large extent orginating from integrated steel mills in industrialized countries.

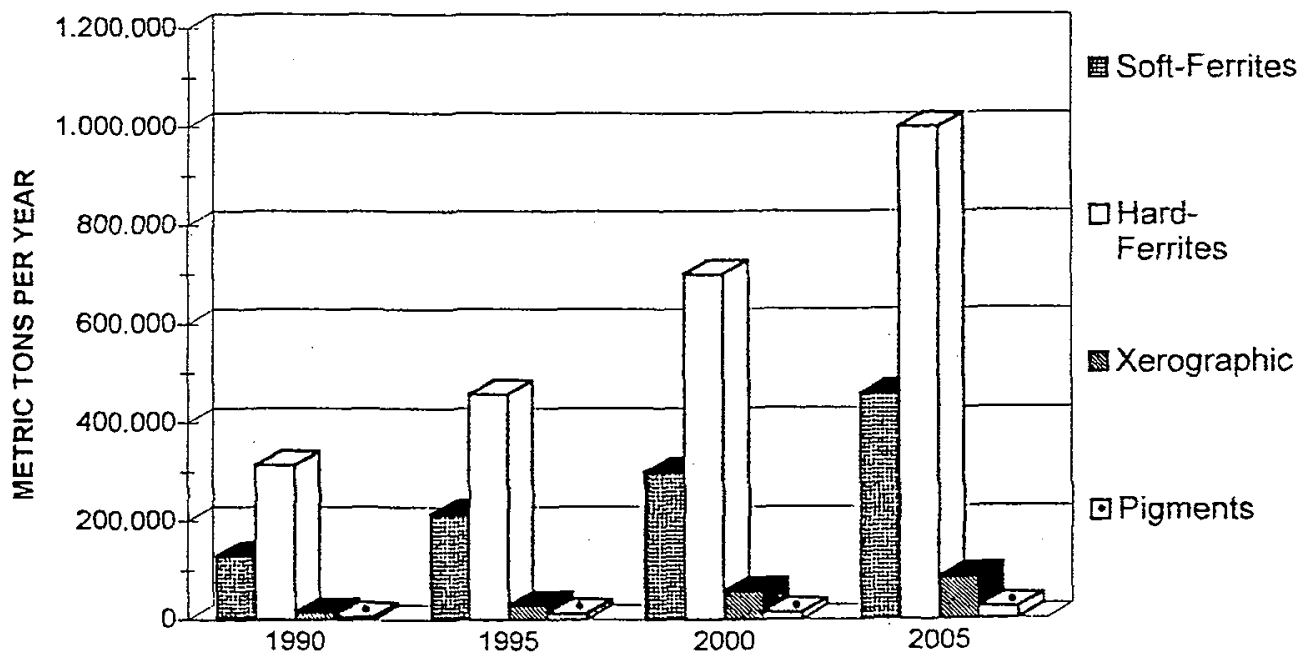

Table 1. Estimated world ferrite production in metric tons per year 


\section{Requirements for the Production of More Uniform Ferrite Powders by means of new Ceramic Processing Methods}

For the production of uniform ferrite powders and consequently sintered ferrite cores, exhibiting uniform micro-structures within the lower micron meter range, several processes are presently being applied on an industrial scale. Over $95 \%$ of presintered ferrite powders produced make use of rotary or pendulum kilns, which employ thermal treatments up to 60 minutes, yielding undesirable partly or completely collapsed powder micro structures, which require undesirable long and expensive micronizing milling cycles, yielding consequently to a broad distribution of primary crystal sizes within presintered ferrite powder. Only extremely short presintering reactions are considered to be suitable to keep glass forming impurities uniformly distributed and yield uncollapsed ferrite powders, which are more easily to desagglomerate and yield narrow primary ferrite crystal distributions within submicron meter range.

Further developments, taking experiences with short time solid state powder reactions into consideration and avoiding thermal decomposition procedures of multicomponent metal chloride solutions, resulted in a new calcining method based on commercially available ferrite raw materials [4].

Liquid phase sintering is considered to take place in all ferrite copositions, which contain a few hundred ppm of glass forming agents or require - grain boundary engineering - with selected dopants in order to provide desired specific material properties. Working with p.a. grade or extremely high purity raw materials is for economic reasons only possible for a limited volume of ferrite products.

Large volume ferrite production is accomplished by technical purity raw materials, which are produced in huge quantities exhibiting various levels as well as fluctuations of impurities. Due considerations should be given in any publication to precisely provide data on the nature of glass forming agents down to the lower ppm range for better understanding of mechanism, which control formation of uniform micro-structures. In addition to provided analytical data all energy consuming unit processes, like thermal treatments and milling / desagglomeration procedures, should be minimized in order to provide presintered ferrite powders and finished ferrite products with more uniform distribution of impurities and primary crystal sizes.

Table 2. indicates the different crystal growth and milling / desagglomeration cycles for three ferrite powder calcining processes. The production of ferrite powders by means of rotary kiln processing is still characterized by extensive zone refining effects yielding to undesired statistical distribution of glass forming impurities, which upon subsequent milling operations may not be uniformely distributed and cause undesired duplex micro-structures upon final sintering. Ferrite powders produced by extremely short thermal treatments and subsequent milling/desagglomeration cycles, like co-roasting [5] or vertical furnace processing, yield upon precise controll of processing parameters uncollapsed ferrite powders exhibiting a more uniform distribution of impurities. To be more specific, a series of process parameters, characteristic for the long processing cycle of rotary kiln calcining, have been compared with short processing cycles as provided by means of a short thermal treatment within a vertical furnace, and compiled for the production of strontium-hexaferrite powders, in Table 3. Requirements for the production of more uniform ferrite powders may be summarized as follows:

Raw Materials

* Improve stability of ferrite raw materials impurity levels $\&$ reduce of hard agglomerates

* Promote reduction of residual salts \& increase and stabilize specific surface area data $\left(+/-0.25 \mathrm{~m}^{2} / \mathrm{g}\right)$

* Avoid milling equipment, which is useless to desintegrate hard agglomerates

* Use binder systems, which burn-off free of residues $\&$ abolish inappropriate measuring technics

* Avoid ferrite raw materials exhibiting collapsed powder microstructures

Thermal Processing

* Use extremely short \& precisely controlled presintering technics for ferrite powder production

* Avoid production of powders exhibiting collapsed powder microstructures

* Further reduce metal salts to less than $100 \mathrm{ppm}$

* Consider indirect heating technics for top of the line ferrite powders

* Control the powder cooling cycle precisely \& provide rapid quality adjustment and control features

Subsequent Ferrite Powder Processing

* Optimization of short desagglomeration cycles within the submicron meter range 


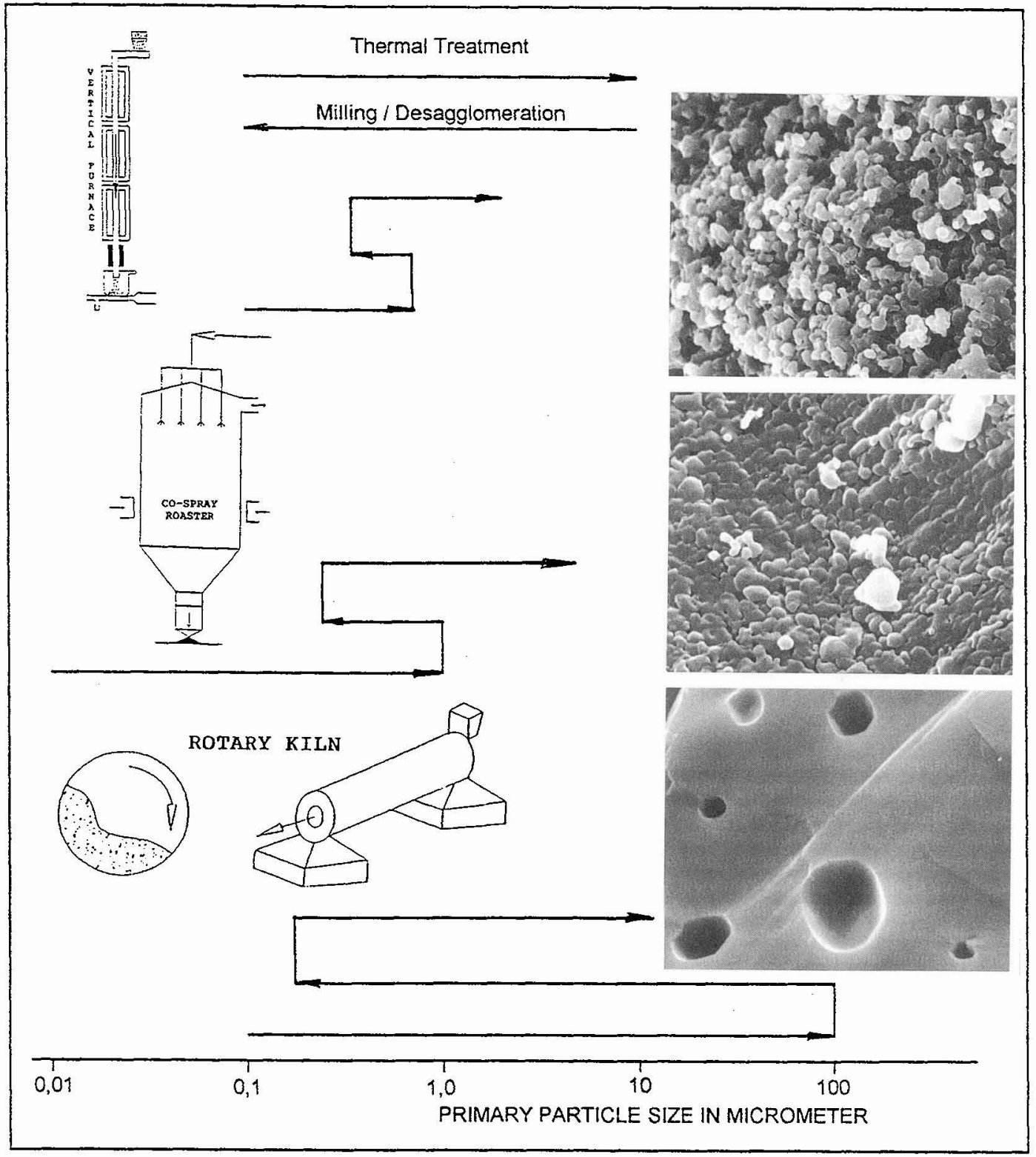

Table 3. Different primary crystal growth and milling/desagglomeration cycles characteristic for three different ferrite powder calcining processes; (1) Rotary Kiin, (2) Co-Spray Roasting and (3) Vertical Fumace

$$
10 \mu \mathrm{m}
$$

\section{Conclusions}

There are substantial possibilities to further improve the performance of finished ferrite products by improving a series of unit ceramic processes and operating parameters related to ferrite raw material properties, short thermal treatments, subsequent desagglomeration, granule production, or slurry processing, pressing as well as final processing steps. Substantial cost savings and quality improvements will become available as soon as more metallurgical and/or chemical industries make use of by-product ferric oxides and produce more precisely engineered presintered ferrite powders on a large scale. 


\begin{tabular}{|c|c|c|}
\hline $\begin{array}{l}\text { FERRITE POWDER-S6F } \\
\text { PROCESS PARAMETERS }\end{array}$ & $\begin{array}{l}\text { ROTARY KILN } \\
\text { PROCESS } \\
\end{array}$ & $\begin{array}{c}\text { VERTICAL FURNACE } \\
\text { PROCESS }\end{array}$ \\
\hline $\begin{array}{l}\text { Raw Materials } \\
\text {-synthetic } \\
\text {-natural } \\
\text { Molar Ratio SrO.6Fe }{ }_{2} \mathrm{O}_{3} \\
\text { Raw Material Feed } \\
\text {-granules, unclassified } \\
\text {-granules, classified } \\
\text {-slumy } \\
\text {-granules size } \\
\text { Thermal Treatment } \\
\text { - granule explosion } \\
\text {-explosion of slurry } \\
\text { - -ust formation } \\
\text {-green granule softening } \\
\text {-tixotropic effects } \\
\text {-moisture content } \\
\text {-local concentration of impurities } \\
\text {-general temperature range } \\
\text {-temperature range SF6 } \\
\text {-temperature control range } \\
\text {-change of process parameters(thermal) } \\
\text {-retention time in seconds } \\
\text {-change of temperature profile } \\
\text {-temperature difference at feed material } \\
\text { upon heating } \\
\text {-crystal neck growth control } \\
\text {-clinker formation } \\
\text {-specific surface control (BET) } \\
\text {-self sintering of selected raw materials } \\
\text { - desired change of product } \\
\text {-precisely control of microstructure } \\
\text {-primary particle size distribution } \\
\text {-reduction of volatile matter } \\
\text {-thermal shielding of feed material } \\
\text {-material flow } \\
\text {-control of molar composition } \\
\text {--residual saits removal } \\
\text {-losses of metal oxides with higher } \\
\text { vapour pressures } \\
\text {-quality adjustments during production } \\
\text { and control cycle } \\
\text { Subsequent Milling andior } \\
\text { Desagglomeration } \\
\text {-time required } \\
\text {-fines } \\
\text {-primary particle size distribution }\end{array}$ & $\begin{array}{c}\text { yes } \\
\text { yes } \\
5.3-5.7 \\
\text { yes } \\
\text { not usual } \\
\text { yes } \\
3.0-7.0 \mathrm{~mm} \\
\\
\text { observed } \\
\text { observed } \\
\text { yes } \\
\text { yes } \\
\text { yes } \\
15-30 \text { wt. } \% \\
\text { yes } \\
700-1750^{\circ} \mathrm{C} \\
1200-1350^{\circ} \mathrm{C} \\
+1-20^{\circ} \mathrm{C} \\
\text { siow } \\
1500-3000 \\
\text { within limits } \\
\text { large } \\
\text { not possible } \\
\text { very usual } \\
\text { not possible } \\
\text { frequently } \\
\text { very time } \\
\text { consuming } \\
\text { difficult } \\
\text { broad } \\
\text { lirmited } \\
\text { yes } \\
\text { rolling } \\
\text { fair } \\
\text { good } \\
\text { high } \\
\text { very time } \\
\text { consuming }\end{array}$ & $\begin{array}{c}\text { no } \\
\text { yes } \\
\text { no } \\
150+1-50 \mathrm{um} \\
\text { no } \\
\text { not applicable } \\
\text { no } \\
\text { no } \\
\text { no } \\
0.2-0.5 \mathrm{wi} \% \\
\text { no } \\
700-1800^{\circ} \mathrm{C} \\
1050-1200^{\circ} \mathrm{C} \\
+1-2.5^{\circ} \mathrm{C} \\
\text { fast } \\
1.5-3.0 \\
\text { very flexible } \\
\text { uniform } \\
\text { adjustable } \\
\text { only on purpose } \\
\text { precise } \\
\text { not possible } \\
\text { flexible and very fast } \\
\text { adjustable } \\
\text { narrow } \\
\text { excellent } \\
\text { no } \\
\text { quasi free falling } \\
\text { excellent } \\
\text { excellent } \\
\text { very little } \\
\text { very fast } \\
\end{array}$ \\
\hline
\end{tabular}

Table 4. Process parameters and related presintered ferrite powder properties $\left(\mathrm{SrO} .6 \mathrm{Fe}_{2} \mathrm{O}_{3}\right)$ connected with long (rotary kiln process) and short (vertical fumace process) term thermal processing cycies

\section{References}

[1] M.J. Ruthner, 'Soft Magnetic Materials '96', Gorham/Intertech Conferences, San Francisco 1996

[2] M.J. Ruthner, Proceeding ICF 3, Japan, CAPJ 1981, pp. 64-67

[3] M.J. Ruthner, Proceeding ICF 5, India, Oxford \& IBH Publishing Co., Pvt. Ltd., 1989, pp. 23-34

[4] M.J. Ruthner, Proceeding ICF 6, Japan, The Japan Society for Powder and Powder Metallurgy Tokyo 1992, ISBN4-9900214-3-6, pp. 40-44

[5] T. Ochiai, K. Okutani, Proceeding of ICF 4, USA, The American Ceramic Society, Columbust Ohio 1985, Advances in Ceramics, Vol. 16, pp. 447-446 